\title{
Magnetostratigraphy of the Buntsandstein (Lower Triassic) in the Gorzów Wielkopolski IG 1 borehole, eastern German Basin in Poland: evidence of substantial diachronism of palynostratigraphic macrospore zones
}

\author{
Anna BECKER ${ }^{1, *}$ and Jerzy NAWROCKI ${ }^{1}$ \\ 1 Polish Geological Institute - National Research Institute, Rakowiecka 4, 00-975 Warszawa, Poland
}

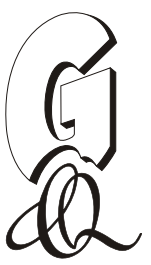

\begin{abstract}
Becker, A., Nawrocki, J., 2014. Magnetostratigraphy of the Buntsandstein (Lower Triassic) in the Gorzów Wielkopolski IG 1 borehole, eastern German Basin in Poland: evidence of substantial diachronism of palynostratigraphic macrospore zones. Geological Quarterly, 58 (2): 369-378, doi: 10.7306/gq.1149

Palaeomagnetic research on the lower and middle Buntsandstein section of the Gorzów Wielkopolski IG 1 borehole, located in mid-western Poland, showed the possibility of existence of short reversed subzones within the first normal polarity zone of the lowermost Buntsandstein (magnetozone Tbn1). The earlier established magnetozones Tbn2 and Tbn4 were not detected. The stratigraphic gap between the middle and upper Buntsandstein included at least magnetozones Tbn6 and Tbr6. The magnetostratigraphic correlation between the investigated section and the Otyń IG 1 section indicates a substantial diachronism of palynostratigraphic zones based on macrospores in the lowermost and middle Buntsandstein.
\end{abstract}

Key words: Buntsandstein, magnetostratigraphy, Gorzów Wielkopolski IG 1, Triassic, western Poland.

\section{INTRODUCTION}

The Gorzów Wielkopolski IG 1 well, located in mid-western Poland (Fig. 1), is one of the most extensively investigated boreholes in Poland, because of the great amount of core material taken during its deepening in the years 1957-1959. The Triassic interval was cored with $90-100 \%$ recovery. The stratigraphy of the Triassic deposits was based on micropalaeontological research, mostly using palynomorphs (e.g.,Orłowska-Zwolińska, 1977, 1984; Fuglewicz, 1980). The palynostratigraphic resolution in the Lower Triassic was not high enough to distinguish specific isochronous horizons. The development of magnetostratigraphy during the last decades has shown that it is one of the best correlation methods for red epicontinental sediments, including the Lower Triassic of Central Europe (e.g., Nawrocki, 1997; Szurlies et al., 2003; Hounslow and Muttoni, 2010). Nawrocki (1997) created a magnetostratigraphic scale for the Lower Triassic of Poland based on cores from boreholes located in the northwestern and southwestern part of Poland (Fig. 1). The Gorzów Wielkopolski IG 1 well is located between these regions and fills a gap in the middle part of Poland, representing the axial part of the German Basin of the Lower Triassic.

* Corresponding author, e-mail: anna.becker@pgi.gov.pl

Received: September 11, 2013; accepted: January 20, 2014; first published online: February 18, 2014

\section{STRATIGRAPHY OF THE BUNTSANDSTEIN IN GORZÓW WIELKOPOLSKI IG 1}

The Buntsandstein group of Poland is subdivided into a lower, middle and upper subgroup. A number of formations were distinguished within these subgroups. In western Poland these are the Baltic Fm., Pomerania Fm., Połczyn Fm. and Barwice Fm. or its lateral facies equivalent Röt fm. (e.g., Szyperko-Śliwczyńska,1973; Gajewska and SzyperkoŚliwczyńska, 1979; Szyperko-Teller et al., 1997). According to Szyperko-Śliwczyńska (1973; see also CBDG version 2008) the Buntsandstein in the Gorzów Wielkopolski IG 1 borehole is divided into three parts: Baltic Fm. at the bottom, Pomerania $\mathrm{Fm}$. in the middle, and Röt fm. at the top (Fig. 2). The middle Buntsandstein of this region is composed of the Pomerania and Połczyn formations. A stratigraphic gap including the whole Połczyn Fm. was reported between the middle and upper Buntsandstein in the Gorzów Wielkopolski IG 1 borehole (Szyperko-Śliwczyńska, 1973). The Baltic Fm. is underlain by deposits of the upper terrigenous series (referred to as Pzt) of the uppermost Zechstein (CBDG version 2008). Fuglewicz (1980) distinguished the Otynisporites eotriassicus assemblage zone and Kozur (1994) reported the Lundbladispora obsoleta-Lunatisporites noviaulensis assemblage zone within the Baltic Fm. (Fig. 2). The biostratigraphy of the Pomerania $\mathrm{Fm}$. is based on palynology (Fig. 2) with the Trileites polonicus-Pusulosporites populosus assemblage zone, distinguished by Fuglewicz (1980), ranging almost through the whole vertical profile of the formation. Marcinkiewicz (1992) revised this zone splitting it into the Trileites polonicus and Talchirella daciae assemblage zones. Nevertheless, she has not reported her results from the Gorzów Wielkopolski IG 1 directly but from 


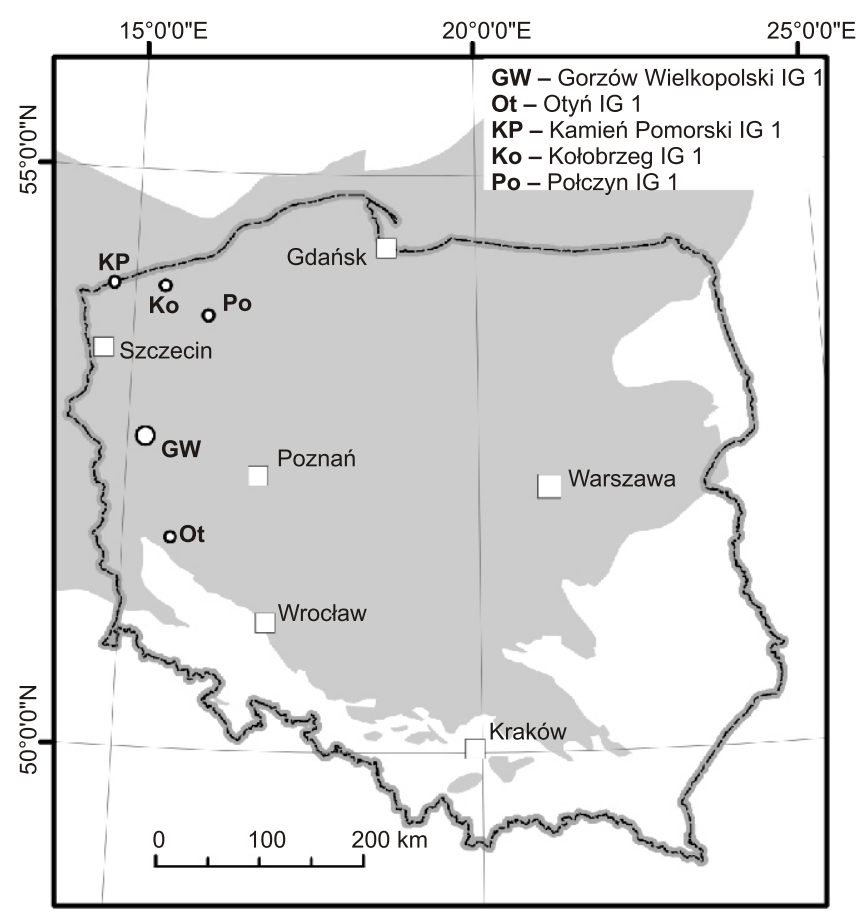

Fig. 1. Location of the Gorzów Wielkopolski IG 1 borehole and boreholes investigated by Nawrocki (1997)

Grey polygon - extent of Germanic Triassic in Poland after Szyperko-Teller and Moryc (1988), Dadlez et al. (2000) and Bachmann et al. (2010)

other boreholes of the Fore-Sudetic Monocline. Orłowska-Zwolińska (1984) distinguished the Densoisporites nejburgii assemblage zone with the Densoisporites nejburgii-acritarcha subzone in the lowermost part of the Pomerania Fm. and the Densoisporites nejburgii subzone in its uppermost part. Becker (2005) proposed a cyclostratigraphic subdivision of the Baltic and Pomerania formations, distinguishing 29 small-scale lithostratigraphic cycles, based on methodology of Röhling (1991, 1993) and Szurlies (2001), and defined four base-level cycles of higher order within the Pomerania Fm., using the sequence stratigraphic concepts (e.g., Shanley and McCabe, 1994; Nystuen, 1998; Catuneanu et al., 2009; Fig. 2). The weakness of the interpretation of Becker (2005) was lacking calibration by means of independent isochronous horizons (e.g., precise biostratigraphy, tuffs, magnetozone boundaries). The Triassic age of the whole Buntsandstein succession was interpreted by Orłowska-Zwolińska (1984) (see also CBDG version 2008). Following Fuglewicz (1980) and Kozur (1994), the lower part of the Baltic Fm. should be of Permian age. The problem of chronostratigraphic interpretation of palynologic zones has not been fully resolved until this study (for further discussion see Becker, 2014).

\section{MATERIAL AND METHOD}

A total of 138 samples, mostly of red, brownish, greenish-grey siltstones and claystones, were taken for palaeomagnetic investigation from the Gorzów Wielkopolski IG 1 borehole (Fig. 3). A few reddish sandstones and grey limestones were also sampled. 122 samples represented the Baltic and Pomerania formations, eight came from the uppermost Pzt

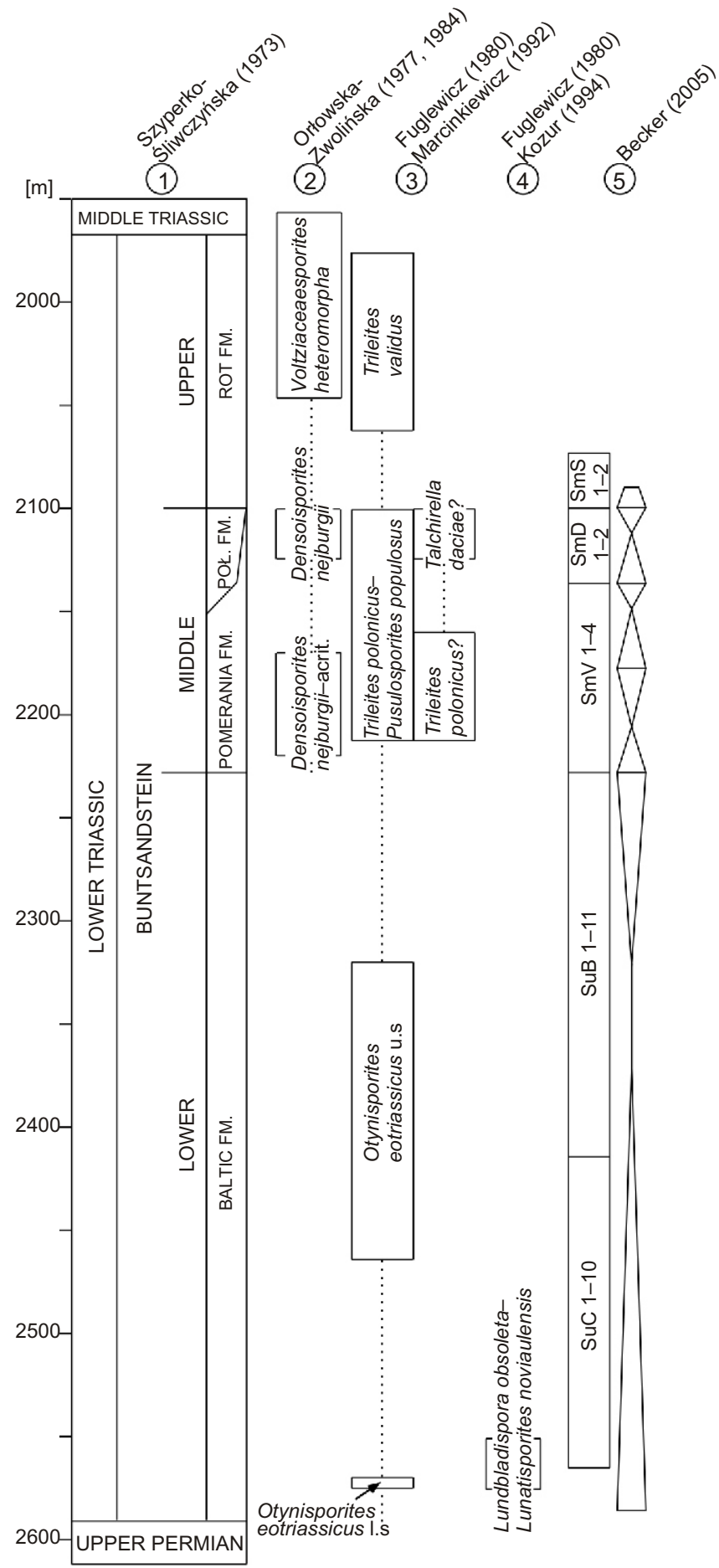

Fig. 2. Stratigraphy of the Buntsandstein in the Gorzów Wielkopolski IG 1 borehole

1 - lithostratigraphy, 2 - palynostratygraphy from miospores, 3 palynostratigraphy from macrospores, 4 - palynostratigraphy, 5 cyclo- and sequence stratigraphy; dotted lines denote barren intervals

part of the Zechstein group and eight from the lowermost Röt $\mathrm{fm}$. One cubic specimen of $2.2 \mathrm{~cm}$ side length was cut off from each core sample. Magnetic susceptibility was monitored using the $K L Y-2$ susceptibility bridge for each specimen subjected to stepwise demagnetization in the MMTD1 oven up to temperatures at or below $650^{\circ} \mathrm{C}$. The natural remanent magnetization (NRM) of specimens was measured using the JR6A spinner 
magnetometer. Principal component analysis (Kirshvink, 1980) was used to calculate the components of NRM using the software developed by Lewandowski et al. (1997). Diagrams representing the results were prepared using the AGICO software. Stable demagnetization components, defined according to the Kirschvink method, showed the inclinations similar to the expected Early Triassic inclinations for the locality $\left(25-40^{\circ}\right.$, see Table 1 and Fig. 3). These provided the basis for the magnetic polarity interpretation, and classification according to the reliability criteria of Nawrocki (1997). The Triassic magnetization is mostly carried by hematite with unblocking temperatures higher than $600^{\circ} \mathrm{C}$ (see Nawrocki, 1997; Szurlies et al., 2003). The first category of reliability based on high quality results from at least two specimens in one sample was not distinguished, because of the lack of additional specimens from one core sample. The results of highest quality were classified as of the second category of reliability (Ilcr, Fig. 3A). If a remanence direction defined by line fitting was lacking, but a clear trend and directional stabilization near the expected inclination was observed, the results were classified to the third category of reliability (IIlcr, Fig. 3A). The magnetic polarity for the core (Fig. 3B) was constructed based on the results from IIcr and IIIcr categories. Single-specimen results of category IIIcr were not used as a basis for distinguishing separate magnetozones, if the polarity was different to adjacent specimens in the core. In such a case, subzones were suggested. During the interpretation, upside down nature of a few core samples could be diagnosed due to the less-stable magnetisation directions with high negative inclinations $\left(50-80^{\circ}\right)$ seen in the early stages of demagnetisation, probably of present-day origin (Fig. 3). It should be noted that present-day inclination is about $+64^{\circ}$ in the study area. We expect high positive inclination and stable end-directions with coherent position defined by relative declination. The reverse position of specimen was interpreted if the initial inclinations showed low negative values (Fig. 3A). This type of results was used only as supplementary data.

\section{MAGNETOSTRATIGRAPHY}

The results of the palaeomagnetic investigation are summarized in Figure 3B. The characteristic inclinations form few narrow intervals of normal and reverse polarity within the vertical section of the lower and middle Buntsandstein. Their depth ranges and mean inclinations are summarized in Table 1. The first normal polarity zone (N1) occurred at the top of the upper terrigenous series (Pzt) and in the lowermost part of the Baltic $\mathrm{Fm}$. up to the depth of $2520.0 \mathrm{~m}$. One sample with negative inclination (IIIcr) occurred at the bottom of the section, suggesting existence of a magneto(sub)zone-boundary. Lack of core material made the polarity interpretation impossible above zone $\mathrm{N} 1$, though one sample with negative inclination was detected between both intervals. The third category of reliability of this result does not allow distinguishing a separate reverse magnetozone. The second normal polarity zone (N2) was dis-

Depth ranges and mean inclinations of the local polarity zones in Gorzów Wielkopolski IG 1

\begin{tabular}{|c|c|c|c|c|}
\hline \multirow{2}{*}{ Local zone } & \multicolumn{2}{|c|}{ Depth [m b. s. I.] } & \multirow{2}{*}{ Mean inclination } & \multirow{2}{*}{ Remarks } \\
\hline & bottom & top & & \\
\hline N1 & 2600.0 & 2520.0 & 29 & $\begin{array}{c}\text { Reverse polarity IIIcr at } 2599.6 \mathrm{~m} \text { and } 2520.7 \mathrm{~m} \text {, two reversed } \\
\text { subzones? }\end{array}$ \\
\hline Unknown polarity & 2520.0 & 2513.0 & - & \\
\hline N2 & 2513.0 & 2476.0 & 32 & \\
\hline Unknown polarity & 2476.0 & 2465.2 & - & \\
\hline R1 & 2465.2 & 2396.2 & -26 & Normal polarity? at $2398.2 \mathrm{~m}$, normal subzone? \\
\hline Unknown polarity & 2396.2 & 2385.0 & - & \\
\hline R2 & 2385.0 & 2338.5 & -35 & \\
\hline N3 & 2338.5 & 2294.5 & 31 & \\
\hline R3 & 2294.5 & 2236.0 & -23 & \\
\hline Unknown polarity & 2236.0 & 2202.4 & - & \\
\hline R4 & 2202.4 & 2190.0 & -29 & \\
\hline Unknown polarity & 2190.0 & 2183.0 & - & Normal polarity in reversed sample at $2187.2 \mathrm{~m}$, normal subzone? \\
\hline R5 & 2183.0 & 2156.0 & -25 & \\
\hline N4 & 2156.0 & 2150.2 & 24 & \\
\hline R6 & 2150.2 & 2120.2 & -28 & \\
\hline Unknown polarity & 2120.2 & 2099.0 & - & \\
\hline N5 & 2099.0 & 2071.0 & 30 & \\
\hline Unknown polarity & 2071.0 & 2060.7 & - & \\
\hline \multicolumn{3}{|l|}{ For all zones } & I28I & \\
\hline
\end{tabular}


A GEO $\quad$ (Lambert) $-\mathrm{N}$

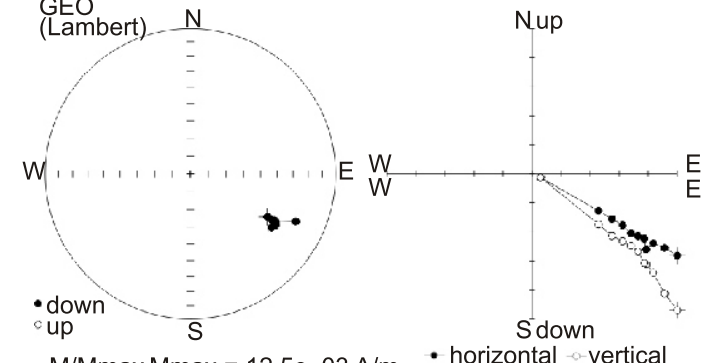

$\mathrm{M} / \mathrm{Mmax} \mathrm{Mmax}=12.5 \mathrm{e}-03 \mathrm{~A} / \mathrm{m} \quad \cdot$ horizontal vertical

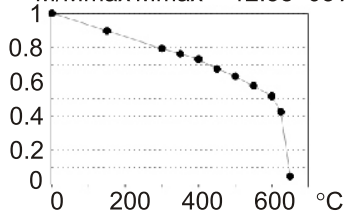

Normal polarity, Ilcr $2086.03 \mathrm{~m}$ b.s.I.

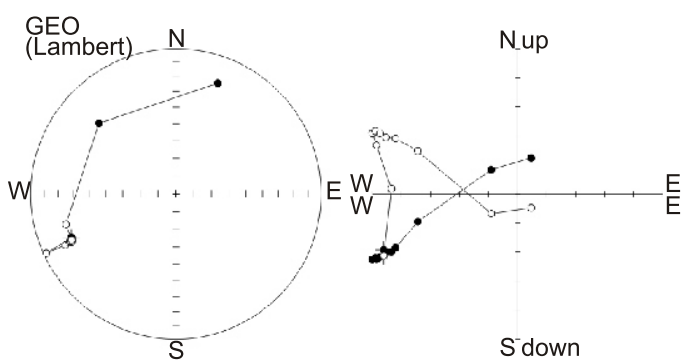

$\mathrm{M} / \mathrm{Mmax} \mathrm{Mmax}=3.78 \mathrm{e}-03 \mathrm{~A} / \mathrm{m}$

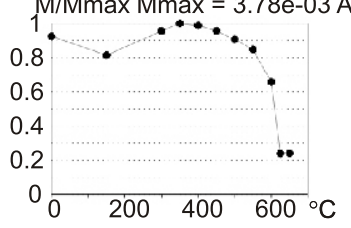

unit $=643 . \mathrm{e}-06 \mathrm{~A} / \mathrm{m}$

Reverse polarity, IIcr $2436.61 \mathrm{~m}$ b.s.I.
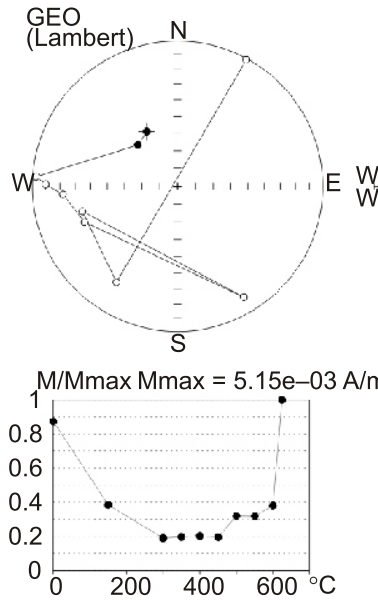

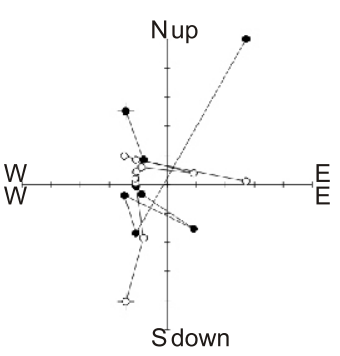

unit $=906 . e-06 \mathrm{~A} / \mathrm{m}$

Reverse polarity, IIIcr 2463.20 m b.s.I.
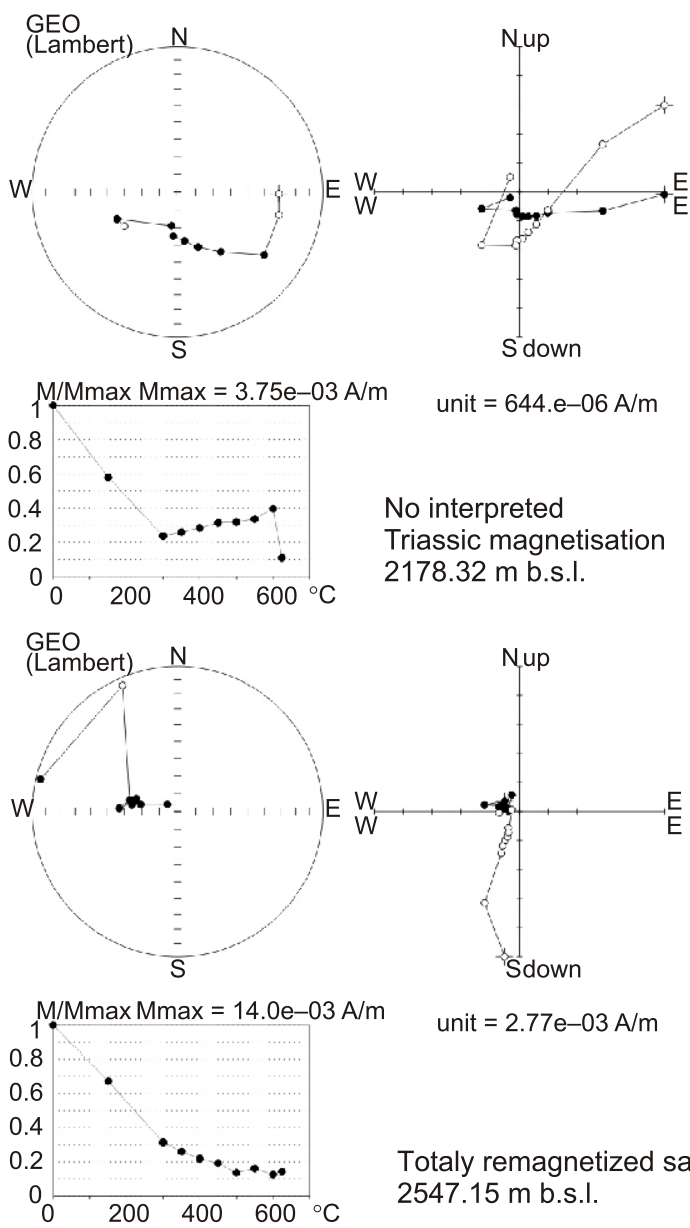

unit $=2.77 \mathrm{e}-03 \mathrm{~A} / \mathrm{m}$

Totaly remagnetized sample $2547.15 \mathrm{~m}$ b.s.l.
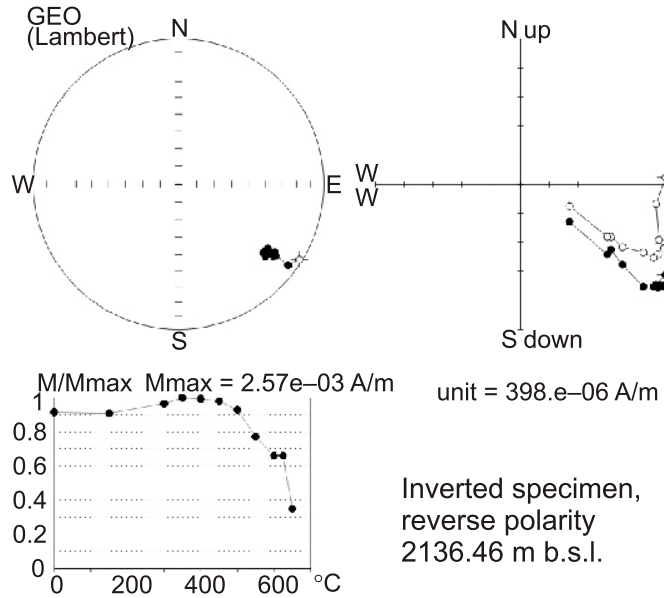

Fig. 3. Results of palaeomagnetic research A - examples of demagnetizing diagrams for samples of reliability classes II and III and of remagnetized sample, 


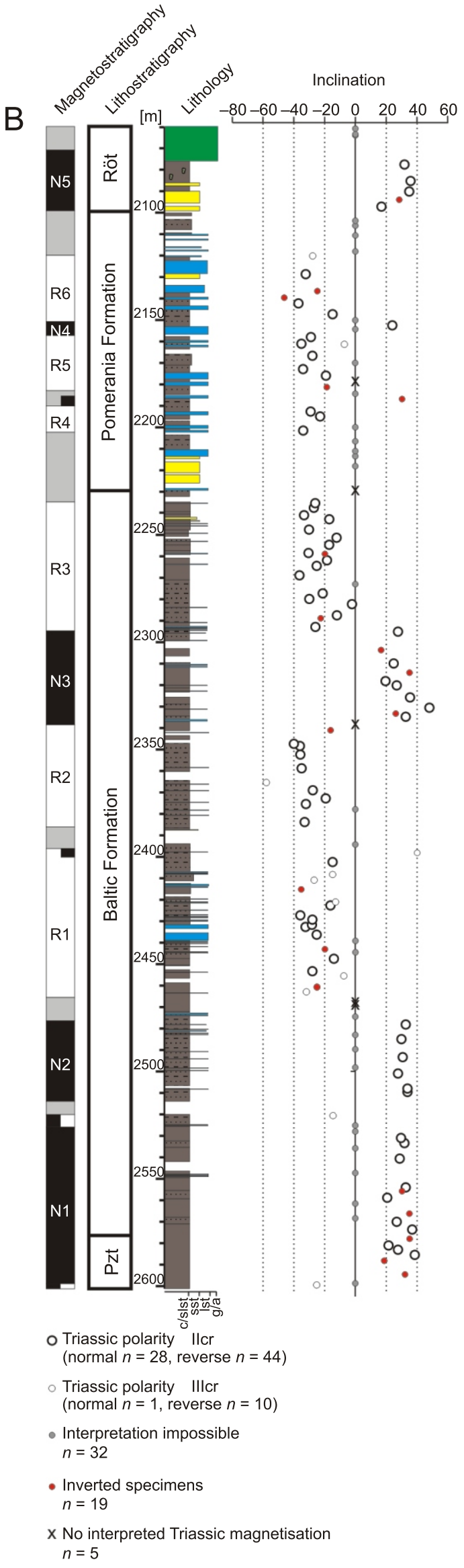

of the Gorzów Wielkopolski IG1 borehole

B - magnetostratigraphy of the lower and middle Buntsandstein; c/slst - clay- and siltstones, sst - sandstones, Ist - limestones, g/a - gypsum/anhydrites tinguished within the lower part of the Baltic Fm. The middle part of the Baltic Fm. was characterized by reverse polarity. Two magnetozones of reverse polarity R1 and R2 could be distinguished. Polarity interpretation was impossible beneath the zones and between them. One measurement of low quality from a depth of $2398.2 \mathrm{~m}$ showed normal polarity. The upper part of the Baltic Fm. contained two zones of normal (N3) and reverse (R3) polarity. The polarity of the topmost part of the Baltic Fm. and the lowermost part of the Pomerania Fm. up to a depth of $2232 \mathrm{~m}$ was impossible to interpret, because of the ambiguous results and lack of appropriate core material. Almost the whole Pomerania Fm. was characterized by reverse polarity. Three compact zones were distinguished: R4, R5 and R6. Polarity interpretation was impossible between zones R4 and R5, though one sample showed normal polarity. Reverse position of the sample was diagnosed during the interpretation, which disqualified the result as the basis for distinguishing a separate zone. One short zone of normal polarity (N4) occurred between zones R5 and R6. The polarity interpretation of the uppermost part of the Pomerania Fm. was impossible, because of lack of core material and lack of unequivocal results. The lowermost Röt fm. showed normal polarity within zone N5. The polarity interpretation for the three uppermost samples within the Röt $\mathrm{fm}$. was impossible.

\section{CORRELATION WITH THE MAGNETOSTRATIGRAPHIC SCALE FOR POLAND}

The magnetostratigraphic scheme of the lower and middle Buntsandstein in the Gorzów Wielkopolski IG1 borehole fits well to the magnetostratigraphic scale developed for Poland (Nawrocki, 1997; Fig. 4). The local zones of N1 and N2 could be correlated with magnetozone Tbn1, which is the lowermost normal zone of the Lower Triassic (Nawrocki, 1997). Its base is located near the Zechstein and Buntsandstein groups boundary (Nawrocki, 2004). Based on the results from Gorzów Wielkopolski IG 1, the existence of a minor subzone of reverse polarity within zone Tbn1 could not be excluded (see Fig. 3B). Zones R1 and R2 should be correlated with magnetozones Tbr1and Tbr2 (Fig. 4). Zone Tbn2 was not undoubtedly detected in the investigated section, but it could be expected around a depth of $2398.2 \mathrm{~m}$ (Fig. 3B). Zone N3 is correlated very well to zone Tbn3 (Fig. 4). The top of the zone was precisely defined in Gorzów Wielkopolski IG 1. In other locations investigated by Nawrocki (1997), the top of zone Tbn3 was characterized by the lowest uncertainty level as well. Zone R3 corresponded to magnetozone Tbr3. The top of the zone remained undefined in the investigated section, because of the existence of a long interval with undefined polarity above it. Two short normal magnetozones Tbn4 and Tbn5 are characteristic for the Pomerania Fm. in western Poland (Nawrocki, 1997). Zone Tbn4 has not been undoubtedly detected in the Gorzów Wielkopolski IG 1 section, though its location could be expected around a depth of $2187.2 \mathrm{~m}$ (Figs. 3B and 4). The next short zone of normal polarity (N4) occurring in the middle part of the Pomerania Fm. was correlated with zone Tbn5. In this case, zone R4 would correspond to the uppermost part of zone Tbr3. Zone R5 corresponded to zone Tbr4. Zone R6 could be correlated with zone Tbr5 (Fig. 4). Correlation of zone N5 with the Polish magnetostratigraphic scale was the most problematic. Lying above zone Tbr5, the discussed zone could be correlated with zone Tbn6. Zone N5 characterized also the lowermost Röt fm., so it could correspond to Tbn7 zone (see Otyń IG 1 in Fig. 4). This interpretation would imply a gap including at least zones Tbn6 and Tbr6. Such a stratigraphic gap was already 


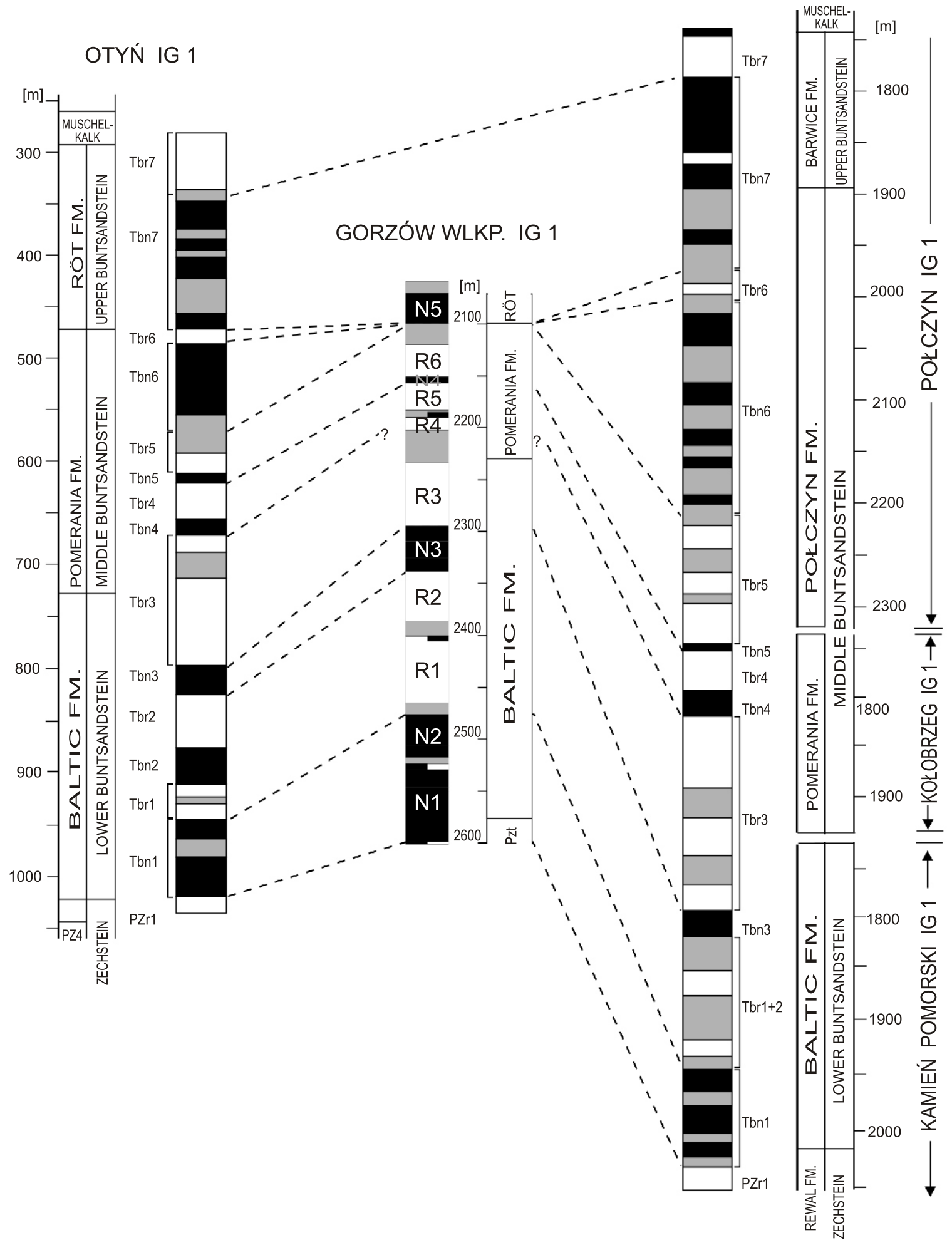

Fig. 4. Correlation of local magnetostratigraphic zones with the magnetostratigraphic scale established for western Poland by Nawrocki (1997)

For location of boreholes see Figure 1 


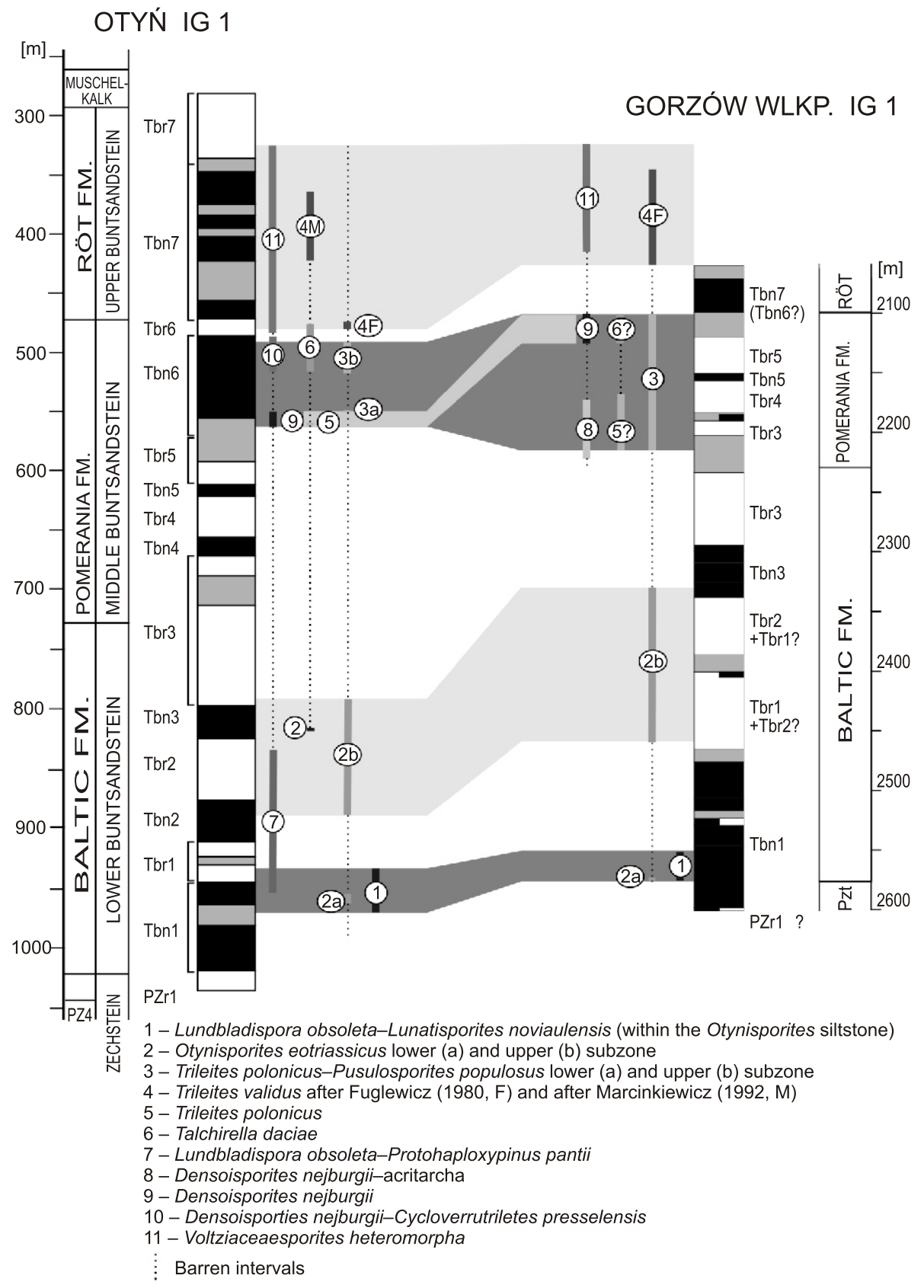

Fig. 5. Correlation of biostratigraphy (palynologic assemblage zones) and magnetostratigraphy between Gorzów Wielkopolski IG 1 and Otyń IG 1 boreholes

For locality of boreholes see Figure 1; references for biostratigraphy: 1 - Kozur (1994) and Fuglewicz (1980); 2a, 2b, 3, 4F - Fuglewicz (1980); 2, 4M, 5, 6- Marcinkiewicz (1992); 7, 8, 9, 10, 11 - Orłowska-Zwolińska (1984)

postulated on the basis of earlier lithostratigraphic and sequence stratigraphic research (Szyperko-Śliwczyńska, 1973; Becker, 2005). The controversial part of the section is barren in terms of palynostratigraphy (Figs. 2 and 5). Nevertheless, the Densoisporites nejburgii zone of Orłowska-Zwolińska (1977, 1984), characterizing the lowermost part of zone Tbn6 in Otyń IG 1, was reported from an interval directly below zone N5, which would suggest a correlation of zone N5 rather with magnetozone Tbn6 (see Fig. 5). The correlation of the Trileites polonicus-Pusulosporites populosus zone of Fuglewicz (1980) as well as the Trileites polonicus and Talchirella daciae zones of Marcinkiewicz (1992) between the two boreholes has proven their diachronism (dark grey correlation in Fig. 5), so they cannot improve the magnetostratigraphic correlation. Summarizing, the correlation of zone N5 with zone Tbn7 was coherent with the earlier lithostratigraphic interpretation. Less probable was the correlation with zone Tbn6, based on the biostratigraphic proxies. On the other hand, zone N5 can correspond to a condensed zone of Tbn6+Tbn7. The stratigraphic gap would include then the whole palynologic zone Densoisporites nejburgii-Cycloverrutriletes presselensis and the lower part of Voltziaceaesporites heteromorpha, which corresponds to the upper part of Tbn6, whole Tbr6 and the lower part of Tbn7 magnetozones (see Fig. 5). 


\section{CONCLUSIONS}

Palaeomagnetic investigation of the lower and middle Buntsandstein of the Gorzów Wielkopolski IG 1 borehole has confirmed the Buntsandstein magnetostratigraphic scheme established by Nawrocki (1997). The possibility of occurrence of reversed subzones within zone Tbn1 could throw a new light on the problem of Permian-Triassic boundary correlation. After Yin et al. (2001), the chronostratigraphic system boundary in the Meishan stratotype section was connected with a palaeomagnetic boundary of reversed and normal polarity zone. This was correlated in the Polish Basin with the boundary between magnetozones Pzr1 and Tbn1 (Nawrocki, 1997, 2004; Nawrocki et al., 2005). If reversed subzones could exist within magnetozone Tbn1, it could not be excluded that the system boundary could be connected with one of the subzone boundaries. Similar subzones within the first Triassic normal polarity zone were reported already by Szurlies (2007: fig. 9 therein). The palaeomagnetic results confirmed the existence of a stratigraphic gap between the middle and upper Buntsandstein, postulated earlier based on lithostratigraphic research
(Szyperko-Śliwczyńska, 1973; Becker, 2005). At least zones Tbn6 and Tbr6 were covered by the gap. The thickness of each magnetic polarity zone differs in different parts of the Polish Basin, which suggests that the sedimentation rates varied within the basin as well. Correlation of isochronous palaeomagnetic zones has shown substantial diachronism not only of the Trileites polonicus-Pusulosporites populosus zone of the middle Buntsandstein but also of the Otynisporites eotriasscus lower subzone corresponding to the Lundbladispora obsoleta-Lunatisporites noviaulensis zone (Fuglewicz, 1980; Kozur, 1994) of the lowermost Buntsandstein (see Fig. 5).

Acknowledgements. The research was financed from the statutory funds (PGI-NRI grant No. 61.2201.0605.00.0 to AB) The authors would like to thank Ms. K. Sobien for conducting the palaeomagnetic measurements and help during the last phase of interpretation. Numerous suggestions of Prof. M. Hounslow (Leicester University) and Prof. J. Szulc (Jagiellonian University, Cracow) improved largely the original version of the manuscript.

\section{REFERENCES}

Bachmann, G.H., Geluk, M.C., Warrington, G., Becker-Roman, A., Beutler, G., Hagdorn, H., Hounslow, M.W., Nitsch, E., Röhling, H.-G., Simon, T., Szulc, A., 2010. Triassic. In: Petroleum Geological Atlas of the Southern Permian Basin Area (ed J.C. Doornenbal and A.G. Stevenson): 149-173. EAGE Publications b.v. (Houten)

Becker, A., 2005. Sequenzstratigraphie und Fazies des Unteren und Mittleren Buntsandsteins im östlichen Teil des Germanischen Beckens (Deutschland, Polen). Hallesches Jahrbuch für Geowissenschaften, Reihe B, Beiheft, 21: 1-117.

Becker, A., 2014. Conchostracan stratigraphy of the Permian/Triassic boundary - reality or myth? (in Polish with English summary). Przegląd Geologiczny, 62: 184-189.

Catuneanu, O., Abreu, V., Bhattacharya, J.P., Blum, M.D., Dalrymple, R.W., Eriksson, P.G., Fielding, C.R., Fisher, W.L., Galloway, W.E., Gibling, M.R., Giles, K.A., Holbrook, J.M., Jordan, R., Kendall, C.G.St.C., Macurda, B., Martinsen, O.J., Miall, A.D., Neal, J.E., Nummedal, D., Pomar, L., Posamentier, H.W., Pratt, B.R., Sarg J.F., Shanley, K.W., Steel, R.J., Strasser, A., Tucker, M.E., Winker,C., 2009. Towards the standardization of sequence stratigraphy. Earth-Science Reviews, 92: 1-33.

CBDG version 2008. Centralna Baza Danych Geologicznych. Litostratygrafia, Chronostratygrafia, weryfikacja 2008. http://otworywiertnicze.pgi.gov.pl

Dadlez, R., Marek, S., Pokorski, J., ed., 2000. Geological map of Poland without Cainozoic deposits 1:1 000 000. Państwowy Instytut Geologiczny, Warszawa.

Fuglewicz, R., 1980. Stratigraphy and palaeogeography of Lower Triassic in Poland on the basis of megaspores. Acta Geologica Polonica, 30: 417-470.

Gajewska, I., Szyperko-Śliwczyńska, A., 1979. Stratygrafia, litostratygrafia i paleogeografia. Pstry piaskowiec dolny i środkowy. Prace Instytutu Geologicznego, 96: 25-37.

Hounslow, M.W., Muttoni, G., 2010. The geomagnetic polarity timescale for the Triassic: linkage to stage boundary definitions. Geological Society Special Publications, 334: 61-102

Kirshvink, J.L., 1980. The least squares line and plane and the analysis of palaeomagnetic data. Geophysical Journal of Royal Astronomical Society, 62: 699-718.
Kozur, H.W., 1994. The correlation of the Zechstein with the marine standard.Jahrbuch der Geologischen Bundesanstalt, 137: 85-103.

Lewandowski, M., Werner, T., Nowożyński, K., 1997. A package of FORTRAN programs for paleomagnetic data analysis (manuscript). Program Manual Instituteof Geophysics, Polish Academy of Sciences.

Marcinkiewicz, T., 1992. Megaspore stratigraphical scheme of the Buntsandstein sediments in Poland (in Polish with English summary). Biuletyn Państwowego Instytutu Geologicznego, 368: 65-96.

Nawrocki, J., 1997. Permian to Early Triassic magnetostratigraphy from the Central European Basin in Poland: Implications on regional and worldwide correlations. Earth and Planetary Science Letters, 152: 37-58.

Nawrocki, J., 2004. The Permian-Triassic boundary in the Central European Basin: magnetostratigraphic constraints. Terra Nova, 16: 139-145.

Nawrocki, J., Pieńkowski, G., Becker, A., 2005. Conchostraca (clam shrimps)from the lowermost Buntsandstein at Zachełmie, Holy Cross Mts, central Poland - discussion (in Polish). Przegląd Geologiczny, 53: 222-225.

Nystuen, J.P., 1998. History and development of sequence stratigraphy. Norwegian Petroleum Society, Special Publications, 8: 31-116.

Orłowska-Zwolińska, T., 1977. Palynological correlation of the Bunter and Muschelkalk in selected profiles from Western Poland. Acta Geologica Polonica, 27: 417-430.

Orłowska-Zwolińska, T., 1984. Palynostratigraphy of the Buntsandstein in sections of western Poland. Acta Palaeontologica Polonica, 29: 161-194.

Röhling, H.-G., 1991. A lithostratigraphic subdivision of the Lower Triassic in the Northwest German Lowlands and the German sector of the North Sea, based on Gamma-Ray and Sonic logs. Geologisches Jahrbuch, A119: 3-24.

Röhling, H.-G., 1993. Der untere Buntsandstein in Nordwest- und Nordostdeutschland - ein Beitrag zur Vereinheitlichung der stratigraphischen Nomenklatur. Geologisches Jahrbuch, A142: 149-183. 
Shanley, K.W., McCabe, P.J., 1994. Perspectives on the sequence stratigraphy of continental strata. AAPG Bulletin, 78: 544-568.

Szurlies, M., 2001. Zyklische Stratigraphie und Magnetostratigraphie des Unteren Buntsandsteins in Mitteldeutschland. Ph.D. thesis, University of Halle, Halle (Saale).

Szurlies, M., 2007. Latest Permian to Middle Triassic cyclo-magnetostratigraphy from the Central European Basin, Germany: implications for the geomagnetic polarity timescale. Earth and Planetary Science Letters, 261: 602-619.

Szurlies, M., Bachmann, G.H., Menning, M., Nowaczyk, N.R., Käding, K., 2003. Magnetostratigraphy and high-resolution lithostratigraphy of the Permian-Triassic boundary interval in Central Germany. Earth and Planetary Science Letters, 212: 263-278.
Szyperko-Śliwczyńska, A., 1973. Correlation of the lower and middle Buntsandstein sections in West Poland (in Polish with English summary). Kwartalnik Geologiczny, 17 (2): 261-273.

Szyperko-Teller, A., Moryc, W., 1988. Evolution of the Buntsandstein sedimentary basin in Poland (in Polish with English summary). Kwartalnik Geologiczny, 32 (1): 53-72.

Szyperko-Teller, A., Senkowiczowa, H., Kuberska, M., 1997. Trias dolny (pstry piaskowiec). Prace Państwowego Instytutu Geologicznego, 143: 83-132.

Yin, H., Zhang, K., Tong, J., Yang, Z., Wu, S., 2001. The global stratotype section and point (GSSP) of the Permian-Triassic boundary. Episodes, 24: 102-114. 